\title{
Blockade of pulsatile LH, FSH and testosterone secretion in rams by constant infusion of an LHRH agonist
}

\author{
G. A. Lincoln, H. M. Fraser and M. P. Abbott \\ $M R C$ Reproductive Biology Unit, Centre for Reproductive Biology, 37 Chalmers Street, \\ Edinburgh EH3 9EW, U.K.
}

\begin{abstract}
Summary. Adult Soay rams were infused for 21 days with $50 \mu \mathrm{g}$ buserelin/day, using s.c. implanted osmotic mini-pumps. The continuous treatment with this LHRH agonist induced a supraphysiological increase in the blood concentrations of LH (15-fold) and testosterone (5-fold) followed by a decrease below pre-treatment values after 10 days. The blood concentrations of FSH showed only a minimal initial increase but the subsequent decrease was dramatic, occurring within 1 day. By Day 10 of treatment, the blood concentrations of all 3 hormones were low or declining, $\mathrm{LH}$ pulses were absent in the serial profiles based on 20-min blood samples and the administration of LHRH antiserum failed to affect the secretion of $\mathrm{LH}$ or testosterone. By Day 21 , the secretion of FSH, LH and testosterone was maximally suppressed. The i.v. injection of $400 \mathrm{ng}$ LHRH was totally ineffective at stimulating an increase in the blood concentrations of LH while the i.v. injection of $50 \mu \mathrm{g}$ ovine LH induced a normal increase in the concentrations of testosterone; this confirmed that the chronic treatment with the LHRH agonist had desensitized the pituitary gonadotrophs without markedly affecting the responsiveness of the testicular Leydig cells. The ratio of bioactive:radioimmunoactive LH did not change during the treatment. The long-term effect of the infusion was fully reversible as shown by the increase in the blood concentrations of FSH, LH and testosterone and the return of normal pulsatile fluctuations in $\mathrm{LH}$ and testosterone within 7 days of the end of treatment.
\end{abstract}

\section{Introduction}

Chronic treatment with high doses of LHRH or LHRH agonists causes an inhibition of reproductive function in a wide range of species (rat: Labrie et al., 1978; hamster: Sandow \& Hahn, 1978; dog: Sandow, von Rechenberg, Baeder \& Engelbart, 1980; sheep: Fraser \& Lincoln, 1980; rhesus monkey: Sundaram, Connell, Bardin, Samojlik \& Schally, 1982; Bint Akhtar, Marshall, Wickings \& Nieschlag, 1983; baboon: Vickery \& McRae, 1980; man: Linde et al., 1981; Schürmeyer et al., 1984; Swerdloff \& Bhasin, 1984). The pharmacological effect leads to an initial hyperstimulation of LH and FSH secretion followed by a marked decline in release of both hormones as the pituitary gonadotroph cells become desensitized. If the treatment is continued for many weeks it leads to loss of ovarian cyclicity in the female (Fraser, 1982) or involution of the testes and accessory sex glands in the male (Labrie et al., 1980; Vickery, 1982).

Inhibition can be induced by continuous or intermittent administration of the agonist, with the continuous treatment being more effective at suppressing the pituitary-gonadal axis (Bint Akhtar et al., 1983; Mann, Gould \& Collins, 1984). Studies using rats and sheep have shown that the continuous treatment leads to a rapid reduction in the number of pituitary LHRH receptors and pituitary content of LH and FSH (Amundson \& Wheaton, 1979; Nett, Crowder, Moss \& Duello, 1981; Sandow, 1982), changes not found when daily injections are given over the same period (Clayton, 1982; Sandow, 1982). The effectiveness of the constant treatment has led to the 
development of long-acting agonist implants and slow release preparations suitable for long term suppression of gonadal activity (Walker et al., 1984).

The purpose of the present study was to record in detail the stimulatory and inhibitory effects of continuous infusion with an LHRH agonist on the secretion of LH, FSH and testosterone in the ram. In rams the secretion of LH is markedly pulsatile due to the episodic mode of LHRH release from the hypothalamus and it was predicted that chronic exposure to the LHRH agonist would induce pituitary desensitization, block the stimulatory effects of endogenous LHRH and thus prevent the normal pulsatile fluctuations in the blood concentrations of LH and testosterone. The changes in $\mathrm{LH}$ values were measured by a radioimmunoassay and a bioassay method to assess possible changes in the structural characteristics of the LH secreted during the treatment with the agonist.

\section{Materials and Methods}

Eight adult Soay rams weighing 28-32 kg were exposed to alternating 16-week periods of long days (16 h light:8 h darkness) and short days ( $8 \mathrm{~h}$ light:16 $\mathrm{h}$ darkness; lights on at 08:00 $\mathrm{h}$ throughout) to induce full seasonal cycles in pituitary and testicular activity (Lincoln \& Short, 1980). The animals were studied after 12 weeks exposure to short days when gonadotrophin secretion was reaching a maximum and the testes were becoming fully active.

Study 1. One group of 4 rams were infused continuously for 21 days with buserelin, an LHRH agonist, D-Ser $\left(\mathrm{Bu}^{t}\right)^{6} \mathrm{LHRH}-(-1-9)$ nonapeptide ethylamide (Hoechst AG, Frankfurt, West Germany; $50 \mu \mathrm{g} /$ day) using a s.c. implanted minipump (Alzet osmotic pump model 2ML4, Alza Corp., Palo Alto, CA, U.S.A.) placed beneath the skin overlying the ribs and inserted under local anaesthetic. The remaining 4 rams acted as controls, receiving mini-pumps containing $0.9 \%$ saline. All th: mini-pumps were preincubated at $37^{\circ} \mathrm{C}$ for $24 \mathrm{~h}$ before being implanted and were removed on Day 21.

Starting 3 weeks before the treatment and continuing for 3 weeks afterwards, a single blood sample was collected from the jugular vein 3 times weekly at 09:00-11:00 $\mathrm{h}$ from each ram by a venepuncture. At weekly intervals the diameter of the testes and the intensity of the sexual skin flush were recorded (Lincoln \& Davidson, 1977). In addition, sequential blood samples were collected at 20 -min intervals for $16 \mathrm{~h}$ on Day 0 (starting $8 \mathrm{~h}$ before the implantation of the minipumps) and for $8 \mathrm{~h}$ on Days 10 and 21 during the treatment with the agonist and on Day 29 during the recovery period. The first blood sample on each occasion was taken at 08:00 $\mathrm{h}$ at the time of 'lights on'. A cannula was inserted into the jugular vein a day before sampling and kept patent by using heparinized saline. On Day 21 at the end of the treatment with the agonist, all 8 rams were injected i.v. with $400 \mathrm{ng}$ LHRH (Hoechst) and $2 \mathrm{~h}$ later were injected i.v. with $50 \mu \mathrm{g}$ ovine $\mathrm{LH}$ (NIH-LH-S22). Blood samples were collected every $20 \mathrm{~min}$ until $2 \mathrm{~h}$ after the $\mathrm{LH}$ injection.

Study 2. To investigate further the control of $\mathrm{LH}$ and testosterone secretion during the early phase of the infusion of the LHRH agonist (Day 10), LHRH antiserum was used to block any possible effects of endogenous LHRH. Four rams from Study 1 were treated during the next cycle in testicular activity induced by exposure to long days followed by short days. After 12 weeks under short days, the rams were again infused continuously by means of implanted mini-pumps with LHRH agonist as in Study 1. On Day 10 blood samples were collected at 10-min intervals for $14 \mathrm{~h}$ from a cannula placed in the jugular vein. After $8 \mathrm{~h}, 2$ of the rams were given an i.v. injection of $100 \mathrm{ml}$ of a potent LHRH antiserum raised in a ewe (No. 389). This antiserum has $<0.01 \%$ cross-reactivity with buserelin (Ellis, Desjardins \& Fraser, 1983) and the volume of antiserum used had been shown previously to block the normal pulsatile secretion of LH in rams (Lincoln \& Fraser, 1979) and ewes (McNeilly, Fraser \& Baird, 1984).

Radioimmunoassays. All blood samples were heparinized and the plasma was separated and frozen at $-20^{\circ} \mathrm{C}$. Hormone concentrations in the plasma were measured by the radioimmuno- 
assays described previously for FSH (McNeilly, McNeilly, Walton \& Cunningham, 1976), LH (Scaramuzzi, Caldwell \& Moor, 1970) and testosterone (Corker \& Davidson, 1978). The FSH assay had a lower limit of detection of $10 \mathrm{ng} / \mathrm{ml}$ plasma using NIH-FSH-S 9 as reference standard, and an intra-assay coefficient of variation (c.v.) of $5 \%$. The corresponding values were $0.2 \mathrm{ng} / \mathrm{ml}$ plasma (NIH-LH-S18) and a c.v. of $7.5 \%$ for the $\mathrm{LH}$ assay, and $0.1 \mathrm{ng} / \mathrm{ml}$ and a c.v. of $11.5 \%$ for the testosterone assay. All the sequential samples for one animal were measured together in a single assay.

Bioassay. The concentration of LH in the blood plasma was also measured by using a mouse Leydig cell bioassay. Diluted plasma samples (1:20 and 1:40) were assayed in triplicate by incubation with a crude preparation of mouse Leydig cells $\left(\sim 150000\right.$ cells per tube) for $3-4 \mathrm{~h}$ at $32^{\circ} \mathrm{C}$ under a $95 \%$ air: $5 \% \mathrm{CO}_{2}$ mixture. The resulting medium was assayed for testosterone by using a tritium radioimmunoassay (Corker \& Davidson, 1978); the limit of detection at 1:20 dilution was $0.8 \mathrm{ng} / \mathrm{ml}$ using NIH-LH-S18 as the reference standard. The interassay c.v. was $7 \%(n=5)$ and the intra-assay c.v. was $7 \%(n=72)$, using a medium range quality control.

Statistical analysis. The fluctuations in the concentration of $\mathrm{LH}$ in the plasma profiles were analysed for significant pulses by using the definition of a pulse as two consecutive high values, at least one of which exceeded the mean of the previous two baseline values by $>3$ times the intraassay c.v. The changes in the mean concentration of LH, FSH and testosterone and the number of LH pulses during 5 stages of the experiment (Day 0 pretreatment, Days 0, 10 and 21 of treatment, Day 29 after treatment) were tested for significance by using single factor ANOVAR with repeated measures followed by Duncan's multiple range test to establish the timing of any significant changes compared to the pretreatment period. The analysis of the LH data was performed with and without the values for the initial period of the treatment (Day 0 ) which were very high. The changes in the diameter of the testes in the treated and control rams were compared using the MannWhitney $\mathrm{U}$ test.

\section{Results}

\section{Secretion of FSH, $\mathrm{LH}$ and testosterone}

The daily changes in the concentration of FSH, LH and testosterone in the blood plasma of the rams infused for 21 days with the LHRH agonist are shown in Fig. 1. The results of the more intensive sequential blood sampling are illustrated for a representative treated and control ram in Figs 2(a) and 2(b) and the results for all animals are summarized in Table 1. At the onset of the experiment the animals were fully sexually active as judged by the large size of the testes (diameters of $54.8 \pm 1.7$ and $55.3 \pm 0.5 \mathrm{~mm}$ for the control and treatment group respectively) and the full development of the sexual skin flush. The blood concentrations of FSH, LH and testosterone were high and the $\mathrm{LH}$ profiles were characterized by clearly defined $\mathrm{LH}$ pulses at about 2-h intervals (Fig. 2; Table 1).

The infusion of the LHRH agonist resulted in an initial large and rapid increase in the plasma values of LH and testosterone but only a minimal and transient change in the concentrations of FSH (increased in 2 rams, no change in 2 rams; Fig. 2a). The concentrations of LH peaked on the first day of the treatment and remained above the pretreatment values for up to 7 days, while the testosterone values peaked after some 7 days and remained stimulated for more than 10 days (Fig. 1). During this period the FSH values were already markedly depressed.

On Day 10 of the treatment with the agonist, the mean plasma concentrations of LH were similar to those of the pretreatment period but there were no significant pulses in the LH profiles in spite of clear fluctuations in the values of testosterone which were still increased (Fig. 2a; Table 1).

By Day 21, the stimulatory response to the treatment with the LHRH agonist had ended and the plasma concentrations of all three hormones were markedly suppressed. There were no significant LH pulses, and only minimal fluctuations in the levels of testosterone which remained low throughout. The cessation of treatment at this stage led to a clear recovery within 1 week, with 
Table 1. Summary of the changes in the concentration of FSH, LH and testosterone and the number of LH pulses in the blood plasma of 4 control and 4 LHRH agonist-treated (agonist) rams

\begin{tabular}{|c|c|c|c|c|c|c|}
\hline & \multirow[b]{2}{*}{ Group } & \multicolumn{5}{|c|}{ Days of experiment } \\
\hline & & $\begin{array}{c}\text { Day 0 } \\
\text { (pre- } \\
\text { treatment) }\end{array}$ & Day 0 & Day 10 & Day 21 & $\begin{array}{c}\text { Day } 29 \\
\text { (after } \\
\text { treatment) }\end{array}$ \\
\hline $\begin{array}{l}\text { FSH } \\
(\mathrm{ng} / \mathrm{ml})\end{array}$ & $\begin{array}{l}\text { Control } \\
\text { Agonist }\end{array}$ & $\begin{array}{r}102.3 \pm 23.7 \\
63.7 \pm 17.3\end{array}$ & $\begin{array}{r}110 \cdot 5 \pm 23 \cdot 7 \\
76.9 \pm 22 \cdot 1\end{array}$ & $\begin{array}{l}87 \cdot 1 \pm 18 \cdot 6 \\
15 \cdot 0 \pm 3 \cdot 1^{* *}\end{array}$ & $\begin{array}{l}69 \cdot 0 \pm 16.9^{*} \\
14 \cdot 1 \pm 2 \cdot 8^{* *}\end{array}$ & $\begin{array}{l}70 \cdot 3 \pm 20 \cdot 8 * \\
47 \cdot 3 \pm 12 \cdot 0\end{array}$ \\
\hline $\begin{array}{l}\mathrm{LH} \\
(\mathrm{ng} / \mathrm{ml})\end{array}$ & $\begin{array}{l}\text { Control } \\
\text { Agonist }\end{array}$ & $\begin{array}{l}2.7 \pm 0.5 \\
3.0 \pm 0.5\end{array}$ & $\begin{array}{c}2 \cdot 9 \pm 0 \cdot 4 \\
27 \cdot 9 \pm 4 \cdot 8^{* * *}\end{array}$ & $\begin{array}{l}2.0 \pm 0.5 \\
2.9 \pm 0.9\end{array}$ & $\begin{array}{l}1.4 \pm 0 \cdot 1^{* *} \\
1.9 \pm 0 \cdot 6^{* *}\end{array}$ & $\begin{array}{l}2.2 \pm 0.3 \\
2.6 \pm 0.7\end{array}$ \\
\hline $\begin{array}{l}\text { LH pulses } \\
(\mathrm{No} / 8 \mathrm{~h})\end{array}$ & $\begin{array}{l}\text { Control } \\
\text { Agonist }\end{array}$ & $\begin{array}{l}4.0 \pm 0.9 \\
4.3 \pm 0.9\end{array}$ & $\begin{array}{c}2 \cdot 5 \pm 0 \cdot 5 \\
-0\end{array}$ & $\begin{array}{l}3.0 \pm \underset{0^{* * *}}{ \pm} 0 \cdot 4 \\
0\end{array}$ & $\underset{0^{* * * *}}{2 \cdot 8 \pm} 0 \cdot 8$ & $\begin{array}{l}2 \cdot 5 \pm 0.7 \\
4 \cdot 0 \pm 0.6\end{array}$ \\
\hline $\begin{array}{l}\text { Testosterone } \\
(\mathrm{ng} / \mathrm{ml})\end{array}$ & $\begin{array}{l}\text { Control } \\
\text { Agonist }\end{array}$ & $\begin{array}{l}10 \cdot 2 \pm 3 \cdot 1 \\
13 \cdot 0 \pm 1 \cdot 4\end{array}$ & $\begin{array}{l}12 \cdot 6 \pm 3 \cdot 6 \\
25 \cdot 5 \pm 2 \cdot 6^{* *}\end{array}$ & $\begin{array}{c}8 \cdot 9 \pm 2 \cdot 1 \\
22 \cdot 0 \pm 4 \cdot 4^{*}\end{array}$ & $\begin{array}{l}9.4 \pm 2.8 \\
2.8 \pm 0.6^{*}\end{array}$ & $\begin{array}{r}7.9 \pm 1.0 \\
14.4 \pm 2.8\end{array}$ \\
\hline
\end{tabular}

Values are mean \pm s.e.m. for samples collected every $20 \mathrm{~min}$ for $8 \mathrm{~h}$ on the days indicated.

Values significantly different from corresponding pretfeatment period: $* P<0.05,{ }^{* *} P<0.01,{ }^{* * *} P<0.001$.

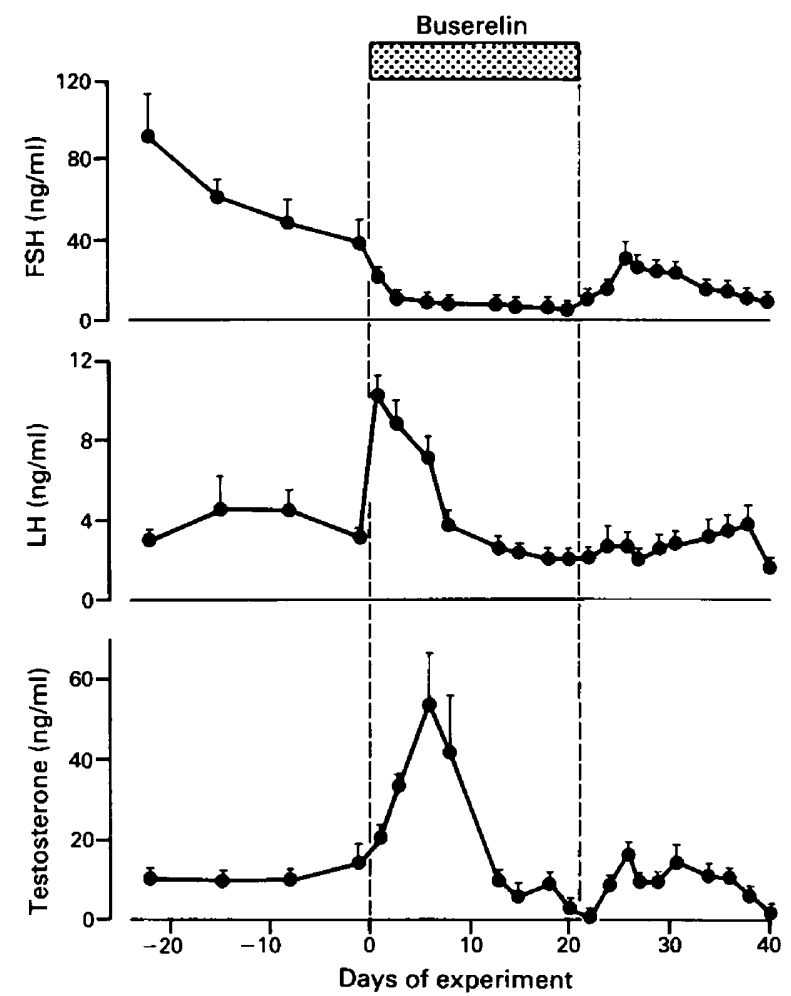

Fig. 1. Daily changes in the concentrations (mean \pm s.e.m., $N=4$ ) of FSH, $\mathrm{LH}$ and testosterone in the blood plasma in a group of 4 sexually mature Soay rams infused for 21 days with an LHRH agonist (buserelin at $50 \mu \mathrm{g} /$ day). 


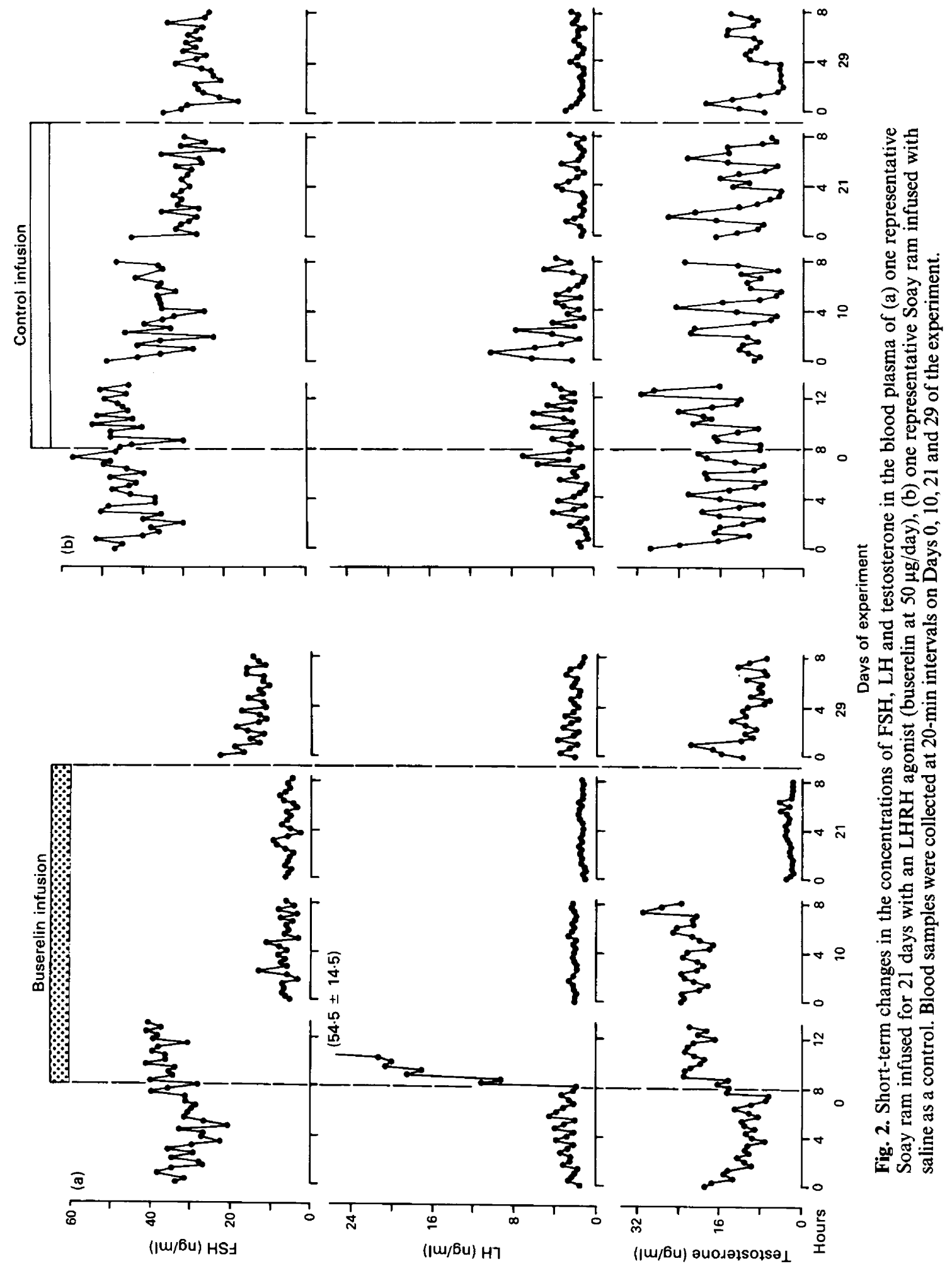


an increase in the plasma concentrations of FSH, LH and testosterone and the reappearance of normal pulsatile patterns of LH secretion (Figs 1 \& 2; Table 1).

There was a small decrease in the diameter of the testes of the rams during the treatment with the LHRH agonist (change for Day 0 to Day 29: 1.0 \pm 0.4 for the control rams and $-1.25 \pm$ $0.5 \mathrm{~mm}$ for the treated rams, $P=0.05$ ), and the sexual skin flush disappeared in all the treated animals.

\section{LH measured by bioassay and radioimmunoassay}

The changes in the concentration of LH measured by both bioassay and RIA for one representative ram treated with LHRH agonist are illustrated in Fig. 3 and the mean values for pooled samples from all animals are summarized in Table 2. The LH values for the pooled samples combined for all stages of the experiment revealed a significant positive correlation between the results for the bioassay and the RIA $(r=0.989, P<0.001)$. Compared to the pretreatment period, the plasma concentrations of $\mathrm{LH}$ were markedly increased at the onset of the treatment with the LHRH agonist and significantly decreased by Day 21 as indicated by both assays (Table 2 ).

For individual samples there was a close correlation between LH values obtained by the bioassay and the RIA for the pretreatment period (Fig. 3; $r=0.829, P=0.001$ ) but this was not

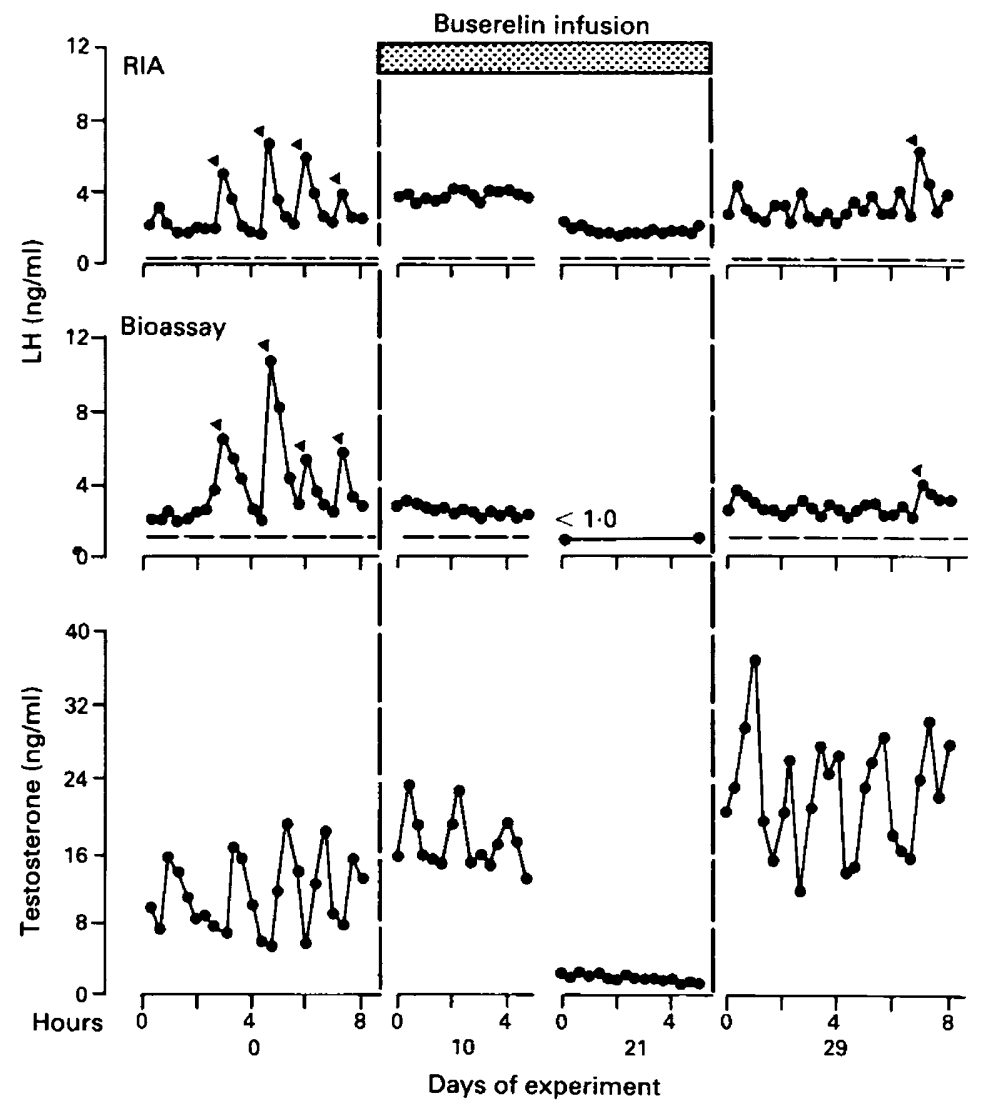

Fig. 3. Short-term changes in the concentration of LH measured by bioassay and radioimmunoassay, and of testosterone in the blood plasma of one Soay ram infused for 21 days with an LHRH agonist (buserelin at $50 \mu \mathrm{g} /$ day). Blood samples were collected at 20-min intervals On Days 0, 10, 21 and 29. Significant LH pulses are indicated ( $\nabla)$. The lower limit of detection for the two LH assays is shown by the broken line. 
Table 2. Summary of the changes in the concentration of $\mathrm{LH}(\mathrm{ng} / \mathrm{ml})$ in the blood plasma of 4 control and 4 LHRH agonist-treated (agonist) rams measured by an ovine radioimmunoassay and a mouse Leydig cell bioassay

\begin{tabular}{|c|c|c|c|c|c|c|}
\hline \multirow[b]{2}{*}{ LH assay } & \multirow[b]{2}{*}{ Group } & \multicolumn{5}{|c|}{ Days of experiment } \\
\hline & & $\begin{array}{c}\text { Day 0 } \\
\text { (pre- } \\
\text { treatment) }\end{array}$ & Day 0 & Day 10 & Day 21 & $\begin{array}{c}\text { Day } 29 \\
\text { (after } \\
\text { treatment) }\end{array}$ \\
\hline RIA & $\begin{array}{l}\text { Control } \\
\text { Agonist }\end{array}$ & $\begin{array}{l}1.75 \pm 0.33 \\
1.93 \pm 0.35\end{array}$ & $\begin{array}{c}3 \cdot 10 \pm 0.82 \\
34 \cdot 95 \pm 5 \cdot 81^{* * *}\end{array}$ & $\begin{array}{l}1 \cdot 15 \pm 0.13 \\
1 \cdot 18 \pm 0.08\end{array}$ & $\begin{array}{l}1.38 \pm 0.26 \\
0.93 \pm 0.05^{* *}\end{array}$ & $\begin{array}{l}1.63 \pm 0.25 \\
1.78 \pm 0.19\end{array}$ \\
\hline Bioassay & $\begin{array}{l}\text { Control } \\
\text { Agonist }\end{array}$ & $\begin{array}{l}1.38 \pm 0.33 \\
1.68 \pm 0.05\end{array}$ & $\begin{array}{c}1.33 \pm 0.28 \\
40.63 \pm 8.45^{* * *}\end{array}$ & $\begin{array}{l}1.05 \pm 0.16 \\
1.58 \pm 0.14\end{array}$ & $\begin{array}{l}0.93 \pm 0.17^{*} \\
0.83 \pm 0.09^{* *}\end{array}$ & $\begin{array}{l}0.88 \pm 0.13^{*} \\
1.43 \pm 0.16\end{array}$ \\
\hline
\end{tabular}

Values are mean \pm s.e.m. for plasma pools produced by combining the first 10 samples from each 20-min sampling period.

Values significantly different from corresponding pretreatment period: ${ }^{*} P<0.05,{ }^{* *} P<0.01,{ }^{* * *} P<0.001$.

evident for the results obtained on Day 10 of the treatment with the agonist, although the values were well above the detection limit for both assays (Fig. 3; $r=-0.099$, NS). No comparison was possible for Day 21 due to the low hormone values but after the end of the treatment the values increased and the correlation between the results for the bioassay and RIA was again apparent (Fig. 3; $r=0.693, P=0 \cdot 01$ ).

\section{Effect of injections of $L H R H$ and $L H$}

After 21 days of treatment with the LHRH agonist the rams were given an i.v. injection of $400 \mathrm{ng} \mathrm{LHRH}$ followed $2 \mathrm{~h}$ later by an i.v. injection of $50 \mu \mathrm{g} \mathrm{LH}$ and the results are illustrated in Fig. 4. The LHRH induced no change in the plasma concentration of LH or testosterone in the rams treated with the agonist while the same dose of LHRH produced a normal response in both hormones in the control animals (Fig. 4). In contrast, the injection of LH induced an increase in the plasma concentrations of testosterone in the treated and control animals, the incremental increase being similar in the two groups (Fig. 4).

\section{Effect of LHRH immunoneutralization}

In Study 2, rams were treated with LHRH agonist for 10 days and then given an i.v. injection of an LHRH antiserum capable of blocking the effect of LHRH secreted endogenously, and the results for one representative ram are shown in Fig. 5. During the initial sampling period the plasma concentrations of $\mathrm{LH}$ were relatively high and constant, and the values of testosterone were also high but with some fluctuations. The injection of the LHRH antiserum had no effect on the concentrations of LH or testosterone (Fig. 5), which remained in the same range as in the control rams.

\section{Discussion}

The continuous infusion of the LHRH agonist into sexually active rams led to an initial stimulation followed by an inhibition of LH and testosterone secretion. The inhibitory effect was fully evident by the end of the 21-day treatment; at this stage the blood concentrations of testosterone were low, the sexual skin flush had disappeared and the testes were showing initial signs of regression. It is not known whether more prolonged treatment would have resulted in marked testicular involution and 


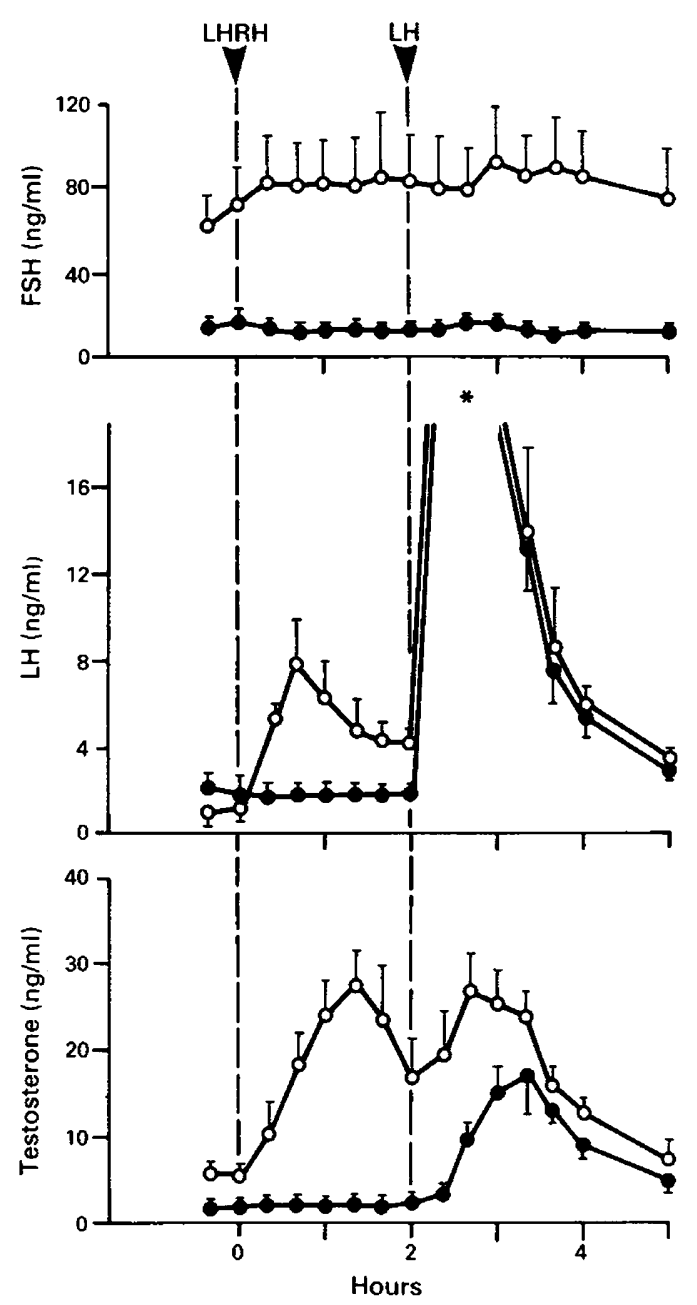

Fig. 4. Changes in the concentration (mean \pm s.e.m., $N=4$ ) of $F S H, ~ L H$ and testosterone in control $(O)$ and LHRH agonist-treated $(\bullet)$ rams studied on Day 21 of the experiment during the i.v. injection of $400 \mathrm{ng} \mathrm{LHRH}$ and later the i.v. injection of $50 \mu \mathrm{g}$ ovine $\mathrm{LH}$. The peak values $\left.{ }^{*}\right)$ for LH after the LH injection were $150-500 \mathrm{ng} / \mathrm{ml}$.

suppression of spermatogenesis, but this is predicted from the effects reported for other species (e.g. rat: Labrie et al., 1978; rhesus monkey: Bint Akhtar et al., 1983; human: Linde et al., 1981).

During the initial treatment with the LHRH agonist there was a striking difference in the response in the changes in the blood levels of $\mathrm{LH}$ compared to FSH. The concentrations of $\mathrm{LH}$ increased at least 15-fold during the first day and remained above normal for $\sim 5$ days. In contrast, the blood levels of FSH showed only a minimal increase at the beginning of the treatment and were markedly decreased below pretreatment values within 1 day. This differential response in the secretion of the two gonadotrophic hormones may be the result of the chronic LHRH agonist treatment leading to a more rapid desensitization of the FSH-secreting mechanisms in the pituitary gonadotrophs, or may be due to the negative feedback effects of sex steroid hormones and inhibin from the testes which act directly on the pituitary cells to inhibit specifically the release of FSH. High circulating concentrations of testosterone were stimulated during the first 10 days of treatment, but there 


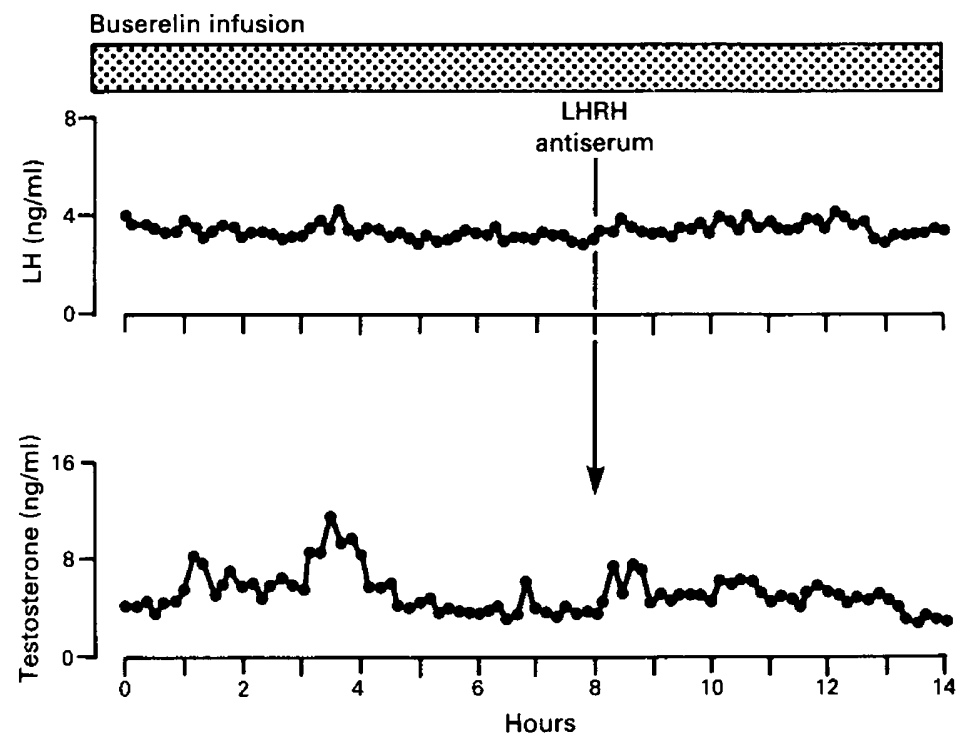

Fig. 5. Short-term changes in the concentration of LH and testosterone in one Soay ram treated for 10 days with a LHRH agonist (buserelin at $50 \mu \mathrm{g} /$ day). Blood samples were collected at 10 -min intervals and after $8 \mathrm{~h}$ the animal received an i.v. bolus injection of $100 \mathrm{ml}$ LHRH antiserum to block any stimulatory effect of LHRH produced endogenously.

is no evidence to indicate a parallel increase in the concentrations of inhibin which is normally controlled by the secretion of FSH (Baker et al., 1983). The preferential suppression of FSH after the continuous infusion of LHRH has been noted in ewes in which the source of gonadal products has been removed by ovariectomy (Nett et al., 1981). This indicates that at least part of the differential response in the secretion of $\mathrm{LH}$ and FSH is independent of the feedback effects from the gonads.

Previous work has shown that the biological activity of LH induced by chronic LHRH agonist treatment can be markedly reduced compared to the activity of LH secreted under physiological conditions and this may not be reflected by the results when a radioimmunoassay is used (Swerdloff \& Bhasin, 1984). However, in the present study there was a very good correlation between the changes in LH revealed by the mouse bioassay and the sheep radioimmunoassay. The only discrepancy was in the results obtained from Day 10 of treatment with the agonist when there was no correlation between the two assays. However, at this time the concentrations of $\mathrm{LH}$ were relatively constant with no significant $\mathrm{LH}$ pulses and the range of values may have been too narrow to assess a meaningful correlation coefficient bearing in mind the assay variation.

While both the assay systems indicated a relatively constant release of LH at Day 10 , there were still conspicuous pulsatile fluctuations in the blood concentrations of testosterone in the rams (Figs $2 \mathrm{a}, 3$ \& 5). This may indicate that there were still small pulses in the release of LH and the ram's own Leydig cells were acutely sensitive to these changes. These LH pulses could reflect the release of endogenous LHRH from the hypothalamus at a stage of the treatment when the pituitary cells were still partly able to respond. However, the main stimulus to the secretion of LH at this time was clearly from the agonist treatment since the administration of an LHRH antiserum failed to block the release of $\mathrm{LH}$ and testosterone (Fig. 5).

During the treatment with the LHRH agonist the blood values of LH gradually declined, indicating a progressive loss of responsiveness to the synthetic agonist and to endogenous LHRH. On Day 21 the injection of a physiological dose of LHRH failed to stimulate the release of LH in the agonist-treated rams, and at this stage there were no significant pulsatile fluctuations in the blood concentrations of $\mathrm{LH}$ and testosterone indicative of responses to the secretion of endogenous 
LHRH. Taken overall, the results illustrate that the continuous exposure to the agonist led to a desensitization of the pituitary gonadotroph cells, thus blocking all effects of LHRH and leading to a decline in the secretion of $\mathrm{LH}$.

A single injection of LHRH agonist given to rams once each day for 8 days has been shown to result in a loss of pituitary responsiveness and a decline in the release of testosterone in response to $\mathrm{LH}$, thus indicating a parallel desensitization of the Leydig cells in the testis (Fraser \& Lincoln, 1980). However, this change in testicular responsiveness was not apparent in the present study since the injection of LH into rams infused with the agonist produced a normal increment in the secretion of testosterone. The mode of administration of the agonist is probably important in this respect since the intermittent treatment produced very high blood levels of $\mathrm{LH}$ after the injection each day for many days, while the concentrations of $\mathrm{LH}$ declined more rapidly during the continuous infusion. In the present study the primary block to reproductive function was clearly at the level of the pituitary; this is similar to findings for the male rhesus monkey infused continuously with LHRH agonist (Bint Akhtar et al., 1983; Mann et al., 1984).

The inhibitory effect of continuous treatment with the LHRH agonist was readily reversible in the rams as judged by the increase in the blood concentrations of FSH, LH and testosterone within 7 days of ending the treatment. The treated rams had a slightly higher LH pulse frequency than did the control rams during the recovery period (Figs 2a \& 2b; Table 1) which may indicate that the inhibition of $\mathrm{LH}$ and testosterone secretion induced by the earlier exposure to the agonist had resulted in enhanced endogenous secretion of LHRH which became apparent in stimulating pulsatile $\mathrm{LH}$ release once the treatment with the agonist had been stopped. This result is similar to that observed during the recovery from once daily injections of LHRH agonist (Fraser \& Lincoln, 1980).

In conclusion, the present study illustrates that the continuous administration of an LHRH agonist to rams leads to initial stimulation followed by inhibition of reproductive function. The primary effect is to cause pituitary desensitization which blocks the stimulatory effect of endogenous LHRH and leads to a loss of pulsatile LH secretion and a decline in testosterone secretion. These effects are readily reversible once the continuous treatment with the agonist is stopped.

We thank Norah Anderson for care of the animals and collection of most of the blood samples; Rhona Cunningham and Lorna Downey for expert technical assistance with the radioimmunoassay; Francis Ebling for advice on the statistical analysis; Dr J. Sandow (Hoechst) for the gift of buserelin and LHRH; and NIAMDDK for the standard preparations of ovine LH and FSH.

\section{References}

Amundson, B.C. \& Wheaton, J.E. (1979) Effects of chronic LHRH treatment on brain LHRH content, pituitary and plasma LH and ovarian follicular activity in the anestrous ewe. Biol. Reprod. 20, 633638.

Baker, H.W.G., Burger, H.G., de Kretser, D.M., Findlay, J.K., Hudson, B., Lee, V.W.K. \& Tsonis, C.G. (1983) Present status of research on inhibin: an appraisal. Clin. Reprod. Fertil. 2, 161-174.

Bint Akhtar, F., Marshall, G.R., Wickings, E.J. \& Nieschlag, E. (1983) Reversible induction of azoospermia in rhesus monkeys by constant infusion of a gonadotropin-releasing hormone agonist using osmotic minipump. J. clin. Endocr. Metab. 56, 534-540.

Clayton, R.N. (1982) GnRH modulation of its own pituitary receptors: evidence for biphasic regulator. Endocrinology 111, 152.
Corker, C.S. \& Davidson, D.W. (1978) The radioimmunoassay of testosterone in various biological fluids without chromatography. J. Steroid Biochem. 9, 373-374.

Ellis, G.B., Desjardins, C. \& Fraser, H.M. (1983) Control of pulsatile LH release in male rats. Neuroendocrinology 37, 177-183.

Fraser, H.M. (1982) Antifertility effects of GnRH. J. Reprod. Fert. 64, 503-515.

Fraser, H.M. \& Lincoln, G.A. (1980) Effects of chronic treatment with an LHRH agonist on the secretion of LH, FSH and testosterone in the ram. Biol. Reprod. 22, 269-276.

Labrie, F., Auclair, C., Cusan, L., Kelly, P.A., Pelletier, G. \& Ferland, L. (1978). Inhibitory effect of LHRH and its agonists on testicular gonadotrophin receptors and spermatogenesis in the rat. Int. J. Androl., Suppl. 2, 303-318. 
Labrie, F., Belanger, A., Cusan, L., Seguin, C., Pelletier, G., Kelly, P.A., Reeves, J.J., Lefebvre, F.A., Lemay, A., Gourdeau, Y. \& Raynaud, J.P. (1980) Antifertility effects of LHRH agonists in the male. J. Androl. 1, $209-228$.

Lincoln, G.A. \& Davidson, D.W. (1977) The relationship between sexual and aggressive behaviour, and pituitary and testicular activity during the seasonal sexual cycle of rams, and the influence of photoperiod. $J$. Reprod. Fert. 49, 267-276.

Lincoln, G.A. \& Fraser, H.M. (1979) Blockade of episodic secretion of luteinizing hormone in the ram by the administration of antibodies to luteinizing hormone releasing hormone. Biol. Reprod. 21, 1239-1245.

Lincoln, G.A. \& Short, R.V. (1980) Seasonal breeding: Nature's contraceptive. Recent Prog. Horm. Res. 36, $1-52$.

Linde, R., Doelle, G.C., Alexander, N., Kirchner, F., Vale, W., Rivier, J. \& Rabin, D. (1981) Reversible inhibition of testicular steroidogenesis and spermatogenesis by a potent gonadotropin-releasing hormone agonist in normal men. New Engl. J. Med. 305, $663-667$.

McNeilly, A.S., Fraser, H.M. \& Baird, D.T. (1984) Effect of immunoneutralization of $\mathrm{LH}$ releasing hormone on LH, FSH and ovarian steroid secretion in the preovulatory phase of the oestrous cycle in ewe. $J$. Endocr. 101, 213-219.

McNeilly, J.R., McNeilly, A.S., Walton, J.S. \& Cunningham, F.J. (1976) Development and application of a heterologous radioimmunoassay for ovine follicle-stimulating hormone. J. Endocr. 70, 67-79.

Mann, D.R., Gould, K.G. \& Collins, D.C. (1984) Influence of continuous gonadotropin-releasing hormone $(\mathrm{GnRH})$ agonist treatment on luteinizing hormone and testosterone secretion, the response to GnRH and the testicular response to human chorionic gonadotropin in male rhesus monkeys. $J$. clin. Endocr. Metab. 58, 262-267.

Nett, T.M. Crowder, M.E., Moss, G.E. \& Duello, T.M. (1981) GnRH-receptor interaction. V. Down regulation of pituitary receptors for $\mathrm{GnRH}$ in ovariectomized ewes by infusion of homologous hormone. Biol. Reprod. 24, 1145-1155.
Sandow, J. (1982) Inhibition of pituitary and testicular function by LHRH analogues. In Progress Towards $a$ Male Contraceptive, pp. 19-40 Eds S. L. Jeffcoate \& M. Sandler. John Wiley and Sons, Chichester.

Sandow, J. \& Hahn, M. (1978) Chronic treatment with LHRH in golden hamsters. Acta endocr., Copenh. 88, $601-610$.

Sandow, J., von Rechenberg, W., Baeder, C. \& Engelbart, K. (1980) Antifertility effects of an LHRH analogue in male rats and dogs. Int. J. Fert. 25, 213-221.

Scaramuzzi, R.J., Caldwell, B.V. \& Moor, R.M. (1970) Radioimmunoassay of $\mathrm{LH}$ and estrogen during the estrous cycle in the ewe. Biol. Reprod. 3, 110-119.

Schürmeyer, T.H., Knuth, U.A., Freischem, C.W., Sandow, J., Bint Akhtar, F. \& Nieschlag, E. (1984) Suppression of pituitary and testicular function in normal men by constant gonadotropin-releasing hormone agonist infusion. J. clin. Endocr. Metab. 59, 19-24.

Sundaram, K., Connell, K.G., Bardin, C.W.,Samojlik, E. \& Schally, A.V. (1982) Inhibition of pituitary-testicular function with [D-Trp ${ }^{6}$ ]-luteinizing hormone-releasing hormone in rhesus monkeys. Endocrinology 110, 1308-1314.

Swerdloff, R.S. \& Bhasin, S. (1984) Hormonal effects of GnRH agonist in the human male: an approach to male contraception using combined androgen and GnRH agonist treatment. In $L H R H$ and its Analogues, pp. 287-301 Eds F. Labrie, A. Belanger \& A. Dupont. Excerpta Medica, Amsterdam.

Vickery, B.H. (1982) Physiology and antifertility effects of LHRH and agonistic analogs in male animals. In LHRH Peptides as Male and Female Contraceptives, pp. 175-290 Eds G. I. Zatuchni, J. D. Shelton \& J. J. Sciarra. Harper and Row, Philadelphia.

Vickery, B.H. \& McRae, G.I. (1980) Effects of continuous treatment of male baboons with super agonists of LHRH. Int. J. Fert. 25, 179-184.

Walker, K.J., Turkes, A.O., Turkes, A., Zwink, R., Beacock, C., Buck, A.C., Peeling, W.B. \& Griffiths, K. (1984) Treatment of patients with advanced cancer of the prostate using a slow-release (depot) formulation of the LHRH agonist ICI 118630 (Zoladex). $J$. Endocr. 103, RI-R4. 